\title{
FENOMEN DOBRA W PERSPEKTYWIE OPIEKI HOSPICYJNEJ
}

\section{Wprowadzenie}

Pragnienie doświadczania dobra ze strony innych charakteryzuje ludzi niezależnie od epoki, w której żyją. Jak wskazują na to przykłady losów ludzkich, dobro świadczone przez jednych względem innych może stać się początkiem zmiany na lepsze u tych ostatnich. Może powodować, że ktoś odzyska wiarę w siebie, w sens własnego życia.

Dobro czynione innym ludziom przemienia także samych dobroczyńców. Często satysfakcja wewnętrzna wynikająca z faktu, że się komuś pomogło, jest wystarczającą nagrodą dla nich. Nie oczekują żadnej gratyfikacji finansowej. Motywuje ona także do podejmowania dalszych wysiłków.

Doświadczanie dobra jest istotne dla człowieka na każdym etapie jego życia. Nabiera jednak szczególnego znaczenia w przypadku osób cierpiących, przewlekle chorych, a zwłaszcza umierających. Ten etap życia człowieka - umieranie - różni się od pozostałych: jeśli poprzednie otwierały drogę do kolejnych, to $\mathrm{w}$ przypadku umierania następnego etapu już nie będzie. Dobro świadczone człowiekowi w tym stadium jego życia stanowi więc dla niego wartość nie do przecenienia. Hospicja, jako miejsca utworzone specjalnie z myślą o ludziach umierających na nowotwory, mają dobro zarówno u źródeł swego powstania, jak i w swej codziennej praktyce.

W praktyce opieki hospicyjnej jest to dobro rozumiane jako postawa etyczna. W tym kontekście można mówić o szczególnej wzajemności: za- 
równo posługujący w hospicjum, poczynając od lekarzy, a kończąc na wolontariuszach, jak i ci, wobec których ta posługa jest spełniana - ludzie umierający, są dawcami dobra jedni wobec drugich. Jednak innego i inaczej. Ludzie posługujący $\mathrm{w}$ hospicjum podejmują wysiłki ulżenia chorym $\mathrm{w}$ ich ogromnym cierpieniu nie tylko fizycznym, ale obejmującym także wymiar duchowy. Umierający natomiast, poprzez swoje zmaganie $\mathrm{z}$ chorobą, podejmowanie wysiłku rozliczenia $\mathrm{z}$ życiem, refleksję nad jakością relacji z bliskimi, przyczyniają się niejednokrotnie do podejmowania głębszych refleksji nad sensem życia przez osoby opiekujące się nimi.

W tym rozumieniu dobra ważne znaczenie ma także biografia. Motywy pragnienia pomocy umierającym obecne u Cicely Saunders - pomysłodawczyni współczesnego ruchu hospicyjnego - miały niewątpliwie korzenie humanistyczne i religijne - chrześcijańską miłość bliźniego. Bliźnim był dla niej każdy człowiek, nieważne, czy wierzący, czy nie. Potrzebował on pomocy $\mathrm{z}$ racji swojej choroby, i to było jedyne i najważniejsze kryterium, by mógł ją otrzymać.

W działalności hospicyjnej Cicely Saunders i zainicjowanego przez nią ruchu można też wskazać na konsekwencje psychologiczne przyjętej etycznej koncepcji dobra. Umierający mieli potrzeby, które komunikowali posługującym im. Osoby opiekujące się chorymi starały się, na ile to możliwe, te potrzeby zaspokoić. Będzie o tym mowa poniżej.

We współczesnym ruchu hospicyjnym, zapoczątkowanym przez działalność charyzmatycznej angielskiej założycielki, można zatem mówić o fenomenie dobra przejawiającym się w konkretnej postawie etycznej czerpiącej z inspiracji religijnej i mającej swoje konsekwencje psychologiczne.

\section{Dobro u początków współczesnego ruchu hospicyjnego}

Dobru, które leży u podstaw współczesnego ruchu hospicyjnego, od samych jego początków towarzyszyła przyjaźn. Połączyła ona dwoje ludzi: angielską pielęgniarkę Cicely Saunders i polskiego Żyda, lotnika umierającego na raka - Dawida Taśmę. Saunders opiekowała się nim w szpitalu św. Łukasza w Londynie. Taśma leżał na sali razem z osobami, które cierpiały na choroby niekończące się śmiercią. Brakowało mu ciszy i spokoju dla dokonania rozrachunku z życiem wobec nadchodzącej śmierci. Cierpiał z powodu bólów nowotworowych i osamotnienia. Saunders świadczyła mu nie tylko pomoc pielęgniarską. Stała się również dla niego podporą 
duchową. Połączyła ich głęboka przyjaźń, która w krótkim czasie, jaki mieli do dyspozycji z racji postępującej choroby Taśmy, przekształciła się w miłość. Któregoś dnia, gdy siedziała przy łóżku Taśmy, zwrócił się on do niej z pytaniem, czy mogłaby zrobić coś, by ustąpił dręczący go niepokój. Na propozycję przeczytania czegoś, odpowiedział: „Nie, pragnę tylko tego, co jest $w$ twoim umyśle i w twoim sercu"1. To wyznanie pobudziło ją do głębokiej refleksji nad tym, jak ważne dla człowieka umierającego jest, by był przy nim ktoś, kto jest mu życzliwy, obecny czasami bez słów, po prostu ofiarowując mu swój czas i wnętrze.

W sytuacji towarzyszenia Polakowi w jego cierpieniu i umieraniu, w Saunders dojrzewało pragnienie utworzenia specjalnego ośrodka dla ludzi terminalnie chorych. Stopniowo uświadamiała sobie, że ludzie w sytuacji takiej jak Taśma doświadczają poczucia osamotnienia, lęku przed wszechogarniającym bólem, potrzebują świadomości, że nie będą sami $\mathrm{w}$ godzinie śmierci. Według niej, ludzie umierający na nowotwór powinni mieć zapewnione godne warunki do dopełnienia swego życia i przygotowania na śmierć. Chodziło jej w pierwszej kolejności o podjęcie działań w celu uśmierzenia bólu związanego z chorobą nowotworową. Umierającym powinno się, jej zdaniem, zapewnić odpowiednią opiekę pielęgniarską dostosowaną do ich potrzeb. Bliscy chorych powinni mieć także możliwość bycia obecnym przy nich częściej i dłużej, niż jest to możliwe w rzeczywistości szpitalnej, gdzie perspektywą jest pomyślne zakończenie choroby i powrót do domu i bliskich. Swoimi planami budowy ośrodka, który spełniałby powyższe wymagania, Saunders dzieliła się z Taśmą. Utwierdzał on ją w konieczności realizacji tej idei. Przekazał jej na ten cel wszystkie swoje skromne oszczędności - pięćset funtów. Saunders nazwała ten czyn pierwszym darem na rzecz hospicjum stacjonarnego i był on dla niej dodatkową motywacją, by zamierzony cel zrealizować ${ }^{\text {. }}$

Saunders poświęciła całe swoje późniejsze życie idei hospicyjnej, która była inspiracją do podjęcia przez Angielkę studiów medycznych. Przekonał ją do tego kroku znajomy chirurg, argumentując, że jako lekarz będzie mogła znacznie więcej uczynić w tej sprawie niż jedynie jako pielęgniarka - jej głos będzie lepiej słyszalny, będą się z nią i jej zdaniem bardziej liczyć

\footnotetext{
${ }^{1}$ C. Saunders, Trwate zasady hospicjum / Enduring Principles of Hospice, [w:] Hospicja nadziei / Hospices of Hope, red. W. Falkowski, E. Lewandowska-Tarasiuk, J.W. Sienkiewicz, tłum. M. Adamczyk, Warszawa - London 2004, s. 18.

2 Zob. C. Saunders, Hospicjum św. Krzysztofa. Notatki z odczytów wygłoszonych w Polsce, tłum. i oprac. H. Bortnowska, Z. Żylicz, [w:] Sens choroby, sens śmierci, sens życia, red. H. Bortnowska, Kraków 1982, s. 226; zob. też: eadem, Trwałe zasady hospicjum, op. cit., s. 18.
} 
w środowisku medycznym i poza nim. Studia lekarskie ukończyła z wyróżnieniem w 1958 roku, mając czterdzieści lat.

Inną osobą, oprócz Dawida Taśmy, która miała głęboki wpływ na życie osobiste Saunders i jej wizję dotyczącą pomocy umierającym na nowotwór, był również Polak - Antoni Michniewicz. Był on jej podopiecznym - już jako lekarki - w Hospicjum św. Józefa w Londynie założonym i prowadzonym przez siostry miłosierdzia. Ich trwająca zaledwie trzy tygodnie znajomość przerodziła się w głębokie uczucie miłości. Pozwoliła ona Saunders dojrzeć wewnętrznie. Równocześnie był to czas, w którym ostatecznie skrystalizowała się w jej umyśle idea opieki hospicyjnej w jej współczesnym rozumieniu - opieki wielowymiarowej, odpowiadającej na adekwatne potrzeby umierających ${ }^{3}$.

Pragnienie zbudowania hospicjum, które spełniałoby cele, jakie mu stawiała Saunders, ziściło się ostatecznie w 1967 roku - w dwadzieścia lat od śmierci Dawida Taśmy, a sześć od śmierci Antoniego Michniewicza. Sfinalizowanie dzieła życia, jakim było to hospicjum, poprzedziło wiele lat starań pielęgniarki, a następnie lekarki, którą do tego, by nie ustawać w wysiłkach, motywowała szczególnie pamięć o dwóch Polakach i zaufanie, jakie w niej pokładali, iż przyczyni się ona do tego, że inni umierający na nowotwór będą mogli godnie dożyć swoich dni i godnie umrzeć.

Założone przez Saunders hospicjum otrzymało za patrona św. Krzysztofa. Wybór tego akurat świętego nie był przypadkiem. Według legendy chrześcijańskiej, był on tym, który przenosił ludzi z jednego brzegu rzeki Jordan na drugi. Czynił tak, by pomóc tym, którzy nie byli w stanie poradzić sobie sami. Podczas jednej z takich przepraw, kiedy niósł na ramionach małe dziecko, okazało się, że był nim sam Jezus Chrystus 4 .

W chrześcijaństwie św. Krzysztof jest uznawany za opiekuna podróżujących. Na życie ludzkie można też patrzeć jako na szczególny rodzaj podróży. Poprzedzające śmierć umieranie jest tak samo ważnym etapem życia jak pozostałe, które były przed nim. Dobrze, jeśli może się ono dokonać w godnym miejscu, takim, jakim jest hospicjum ${ }^{5}$.

W Hospicjum św. Krzysztofa można odnaleźć trwałe ślady jego początków. Do materialnych należy mosiężna tabliczka umieszczona w parapecie głównego okna. Upamiętnia ona pierwszego z Polaków, którym opiekowała

${ }^{3}$ Zob. S. de Boulay, M. Rankin, Okno nadziei. Cicely Saunders - założycielka ruchu hospicyjnego, tłum. I. Sumera, Kraków 2009, s. 120.

4 Stąd wzięło się imię Krzysztofa - od gr. Christophoros - niosący Chrystusa; W. Zaleski, Święci na każdy dzień. Wydanie uzupetnione, Warszawa 1995, s. 423.

${ }^{5}$ Por. K. de Walden-Gałuszko, U kresu. Opieka psychopaliatywna, czyli jak pomóc choremu, rodzinie i personelowi medycznemu środkami psychologicznymi, Gdańsk 1996, s. 14. 
się C. Saunders, i jego dar - pięćset funtów na pierwsze okno: „I will be a window in your Home - the promise of Dawid Tasma of Warsaw who died 25 February 1948 and who made the first gift to St. Christopher's"6. Po latach C. Saunders wyjaśniła, jak rozumie symbol okna w działalności hospicjum:

Przede wszystkim okno oznacza otwarcie; otwarcie na świat oraz na dochodzące i wychodzące zjawiska. Okno jest środkiem domu, dostępnego dla podróżnych w potrzebie, poszukujących bezpieczeństwa i gościnnej przystani; zakłada otwartość pomiędzy nimi wszystkimi. [...] Okno oznacza także otwarcie na to, co niesie przyszłość, podejmowanie nowych wyzwań rzucanych przez zmieniający się świat i rozwijającą się wiedzę medyczną, a także sprostanie wymaganiom stawianym przez pacjentów i ich rodziny?

Słowa D. Taśmy, w których wyrażał on pragnienie bycia obdarowanym myślami i sercem osoby towarzyszącej mu w umieraniu, Saunders po latach tak zinterpretowała, będąc już bogatsza o refleksję i doświadczenie płynące $\mathrm{z}$ towarzyszenia wielu umierającym:

Co oznacza dziś „zrozumienie i serce"? Zrozumienie wiąże się z wszelkimi odkryciami naukowymi, prowadzącymi do skutecznej opieki medycznej. Jest to niekończące się poszukiwanie nowych sposobów zapanowania nad bólem i innymi objawami choroby, psychologicznymi problemami pacjenta i rodziny, cierpieniem egzystencjalnym. Wiąże się z takimi pytaniami, jak: Kim naprawdę jestem? - Jaki jest sens mojego życia? - Kogo pozostawiam i co się z moimi bliskimi stanie? Oznacza to holistyczne podejście, które stanowi najważniejszy element opieki hospicyjnej lub paliatywnej, niezależnie od wybranej terminologii8.

Innym nawiązaniem do osoby tego Polaka było przeświadczenie Saunders o wielkiej wartości jego życia i umierania, choć on sam był przeciwnego zdania. Uważał, że umierając w wieku czterdziestu lat, nie zdołał pozostawić niczego trwałego po sobie. Lekarka była przekonana, że głęboko się mylił. Niejednokrotnie podczas swoich publicznych wystąpień dawała ona wyraz swojej wdzięczności wobec Taśmy, przywołując go z imienia jako tego, który stał się dla niej trwałą inspiracją w relacjach z umierającymi. Nauczył ją, jakie są ich potrzeby i lęki, jakiej pomocy oczekują od innych. Mottem jej działalności z osobami umierającymi prowadzonej w Hospicjum św. Krzysztofa - przyjętym przez inne hospicja czerpiące z tego przykładu -

6 „Będę oknem w Twoim Domu - przyrzeczenie Dawida Taśmy z Warszawy, który zmarł 25 lutego 1948 r. i który przekazał pierwszy dar na rzecz Św. Krzysztofa”; C. Saunders, Trwałe zasady hospicjum, op. cit., s. 25-26.

7 Ibidem, s. 19.

8 Ibidem; zob. też: H. Szmunnes, Wywiad z C. Saunders nadany przez Sekcje Polska Radia BBC w Londynie 9 kwietnia 1989, [w:] Hospicja nadziei, op. cit., s. 24. 
były słowa: „Jesteś ważny dlatego, że jesteś sobą, a więc zrobimy wszystko, co można, nie tylko by pomóc ci umrzeć w pokoju, ale także byś mógł żyć aż do chwili śmierci"9. W toku długiej pracy z osobami umierającymi, na podstawie tego, co oni sami jej mówili, Saunders sformułowała krótko ich życzenia: „Pomóż mi. Wysłuchaj mnie. Zostań ze mną”10.

Niematerialne ślady początków hospicjum londyńskiego można odnaleźć w zasadach obowiązujących w codziennej jego działalności. Mają one na względzie holistycznie pojęte dobro pacjenta, a także jego bliskich. Zasady te wyznaczają również sposób działania innych hospicjów w Europie i na świecie ${ }^{11}$, dla których wzorem stało się to założone przez C. Saunders. Są nimi:

1. Opieka nad ludźmi w końcowym stadium choroby nowotworowej;

2. Kierowanie się zasadami etyki chrześcijańskiej, jednak z szacunkiem dla ludzi innych wyznań lub niewierzących;

3. Traktowanie umierania jako zjawiska naturalnego;

4. Objęcie troską i opieką środowiska społecznego osoby chorej, jej bliskich;

5. Mówienie prawdy choremu i jego rodzinie;

6. Kształtowanie właściwych postaw w społeczeństwie wobec wagi umierania i śmierci ${ }^{12}$.

\section{Dobro w rzeczywistości hospicyjnej}

Dobro w działalności hospicyjnej przejawiało się w określonej postawie etycznej wobec chorych. Miało ono swoje konsekwencje psychologiczne, o których będzie poniżej mowa.

${ }_{9}^{9}$ C. Saunders, Trwate zasady hospicjum, op. cit., s. 23.

${ }^{10}$ P. Krakowiak, Zdążyć z prawdą. O sztuce komunikacji w hospicjum, Gdańsk 2009, s. 63.

${ }^{11}$ Hospicja kierujące się wymienionymi zasadami funkcjonują obecnie niemal na całym świecie. Wielką rolę $w$ powstawaniu pierwszych $w$ danym państwie odgrywała C. Saunders, wygłaszając odczyty, rozmawiając, zachęcając. Tak było np. w Polsce w przypadku Hospicjum im. ks. E. Dutkiewicza w Gdańsku. Więcej na temat rozwoju hospicjów, także w Polsce, zob. E. Sikorska, Narodziny i rozwój wspótczesnej opieki hospicyjnej na świecie, [w:] W stronę człowieka umierającego. O ruchu hospicjów w Polsce, red. J. Drążkiewicz, Warszawa 1989, s. 79-86; B. Kromolicka, Wolontariusz w stużbie człowiekowi umierającemu. Na przykładzie Szczecińskiego Hospicjum Domowego, Szczecin 2000, s. 19-25.

12 Zob. H. Bylińska, Niemocni pomocnicy. O Hospicjum św. Jana Kantego, Poznań 2003, s. 7-8. Por. B. Kromolicka, op. cit., s. 18-19; C. Saunders, Hospicjum św. Krzysztofa, op. cit., s. 264 i nast. D. Kessler sformułował prawa osób umierających, które można odnieść do wymienionych wyżej zasad działalności hospicyjnej; zob. D. Kessler, Śmierć jest częścia życia. O prawo do godnego umierania, tłum. E. Czerwińska, Warszawa 1999, s. 8. 
Idea opieki hospicyjnej C. Saunders, sformułowana i wcielona w życie w Hospicjum św. Krzysztofa w Londynie, wyznaczyła kierunek relacji pacjent - lekarz, a także pacjent - zespół hospicyjny. Ten ostatni składa się z osób różnej profesji: lekarza, pielęgniarki, farmaceuty, psychologa, pracownika socjalnego, duchownego i wolontariuszy. Jednak $w$ tych relacjach to pacjent $\mathrm{i}$ jego potrzeby wyznaczają zakres działania tych osób wobec niego.

Sytuacja zbliżania się do kresu życia, wiążąca się często z nieodłącznym, narastającym bólem fizycznym, jest czasem bardzo trudnym i jednocześnie bardzo ważnym dla osoby umierającej. Jednak wyzwaniem jest nie tylko ból fizyczny. Według R. Woodsona, człowiek umierający doświadcza tak zwanego bólu totalnego, który obejmuje, oprócz wspomnianego bólu fizycznego, także ból psychiczny, społeczny i duchowy.

Ból fizyczny związany jest z rozwijającą się chorobą nowotworową. Pacjenci określają go niejednokrotnie jako wszechogarniający. W hospicjum podejmuje się wysiłek uśmierzenia go chociaż częściowo, jeśli nie jest możliwe uczynienie tego całkowicie. Służy temu terapia paliatywna.

Ból psychiczny spowodowany jest negatywną zmianą, jaka nastąpiła w życiu chorego. Nie może on już pełnić dotychczasowej roli w życiu, traci poczucie bezpieczeństwa, własnej wartości, atrakcyjności związanej z wyglądem zewnętrznym. Człowiek taki może cierpieć z powodu utraty zaufania otoczenia względem siebie samego, a także $z$ powodu postępującej zależności od innych $\mathrm{w}$ sprawach, $\mathrm{z}$ którymi dotychczas radził sobie sam. W związku z tym chory może odczuwać stany depresyjne, niepokój albo pobudzenie.

Ból socjalny jest nie mniej ważny w tej sytuacji i nie sposób go lekceważyć. Na przykład chory, gdy jest przeświadczony o zbyt późnym rozpoznaniu nowotworu i podjętym leczeniu, może odczuwać gniew, widząc nieskuteczność podejmowanych wysiłków w celu przywrócenia mu zdrowia. Niejednokrotnie cierpi z powodu samotności, opuszczenia ze strony bliskich mu dotychczas osób, w tym czasem nawet rodziny, izolacji, cierpi też z powodu niedostatecznej informacji o swoim stanie, braku życzliwości ze strony pracowników służby zdrowia, biurokracji. Potrzebuje porozumienia i zrozumienia, nawet jeśli ze względu na swój stan zdrowia nie okazuje tego jasno.

R. Woodson wymienia jeszcze ból duchowy. Łączy on w sobie lęk przed zjawiskami znanymi, choć negatywnie odbieranymi: cierpieniem, koniecznością pójścia do szpitala, oraz lęk przed tym, co nieznane, nie do przewidzenia: własną śmiercią i jej okolicznościami, losem bliskich po swojej śmierci. Człowiek może odczuwać niepokój wewnętrzny, duchowy, związany z poczuciem winy za sytuacje źle przeżyte w życiu, krzywdy uczynio- 
ne innym, a także związane z utratą sensu i celu życia. Ból ten łączy się z problemami natury zarówno religijnej, jak i kulturowej13.

Kiedyś pacjent C. Saunders, Polak Antoni Michniewicz, zapytany przez nią, jakiego rodzaju opieki najbardziej potrzebuje, odpowiedział: „Chciałbym, żeby ktoś spróbował mnie zrozumieć"14. Lekarka to właśnie czyniła przez kolejne lata wobec umierających. W jednym ze swoich tekstów dała wyraz temu, że stara się rozumieć tę potrzebę, jest na nią wrażliwa i pragnie uwrażliwić na nią innych:

Powinniśmy się zastanowić na niepokojem i depresją, jakie towarzyszą długotrwałej chorobie i utracie władz umysłowych. Musimy pamiętać o upokorzeniach, stracie, poczuciu winy wynikającym z uzależnienia od innych, a także o słabości, niekontrolowaniu czynności fizjologicznych i nieraz rozpaczliwym odczuciu, że jest się odizolowanym od życia i żyjących ${ }^{15}$.

Ból doświadczany na tylu płaszczyznach może uzmysłowić personelowi opiekującemu się chorym, jakie ów człowiek może mieć niezaspokojone potrzeby. Ważne i cenne jest, gdy może je on bezpiecznie wyartykułować i znajdzie zrozumienie. R. Spilling wymienia owe potrzeby. Są to: dobra kontrola objawów, poczucie bezpieczeństwa, uczucie bycia potrzebnym i przekonanie, że nie jest się dla nikogo ciężarem, ludzki kontakt (dotyk), sympatia, wyjaśnienie objawów choroby, możliwość uczestniczenia w podejmowaniu decyzji (poczucie własnej wartości), dawanie i możliwość brania oraz poczucie bycia akceptowanym pomimo różnych nastrojów ${ }^{16}$. Praktyka $\mathrm{w}$ hospicjach pokazuje, iż kiedy osoba ma zaspokajane wspomniane potrzeby, poprawia się jej jakość życia i doświadczany ból się zmniejsza, a nawet może być w pełni uśmierzony. Dzięki temu osoba ta ma możliwość w spokoju przygotować się na odejście. W hospicjum może doświadczyć tak zwanej godnej albo pięknej śmierci, choć to ostatnie określenie może brzmieć paradoksalnie. Model opieki zaproponowany przez placówkę londyńską kierowaną przez C. Saunders zapewnił umierającym na nowotwory taką możliwość:

Temu Hospicjum zawdzięczamy [...] zwrócenie uwagi na problem tzw. „godnej śmierci” („pięknej śmierci”). To jest: niezakłóconej nerwowymi działaniami lekarskimi; bez bólu, ale przy zachowanej świadomości; w spokoju płynącym z posługi

13 Por. J. Ruszkowska, Hospicjum, "Communio. Międzynarodowy Przegląd Teologiczny” 1989, nr 2, s. 96; J. Binnebesel, Pedagogiczne aspekty wolontariatu w hospicjum, [w:] Podręcznik koordynatora wolontariatu hospicyjnego, red. P. Krakowiak, A. Modlińska i in., Gdańsk 2009, s. $218-219$.

${ }^{14}$ S. de Boulay, M. Rankin, op. cit., s. 177.

15 Ibidem.

${ }^{16}$ Omówienie potrzeb według R. Spillinga znajduje się w: J. Binnebesel, op. cit., s. 218. 
religijnej; w otoczeniu najbliższych, w atmosferze miłości i zrozumienia; z uwzględnieniem woli chorego $\mathrm{w}$ podejmowaniu wszelkich działań ${ }^{17}$.

Warto jeszcze zwrócić uwagę na kwestię wiary, otwartości na to, co będzie po śmierci. Sanders, sama anglikanka, głęboko wierząca, okazywała wielki szacunek ludziom innych wyznań i niewierzącym. Utworzone przez nią Hospicjum w jednej z zasad, o których była mowa wyżej, to zapewniało. Bywały sytuacje, że umierający, którzy określali się jako ludzie niewierzący, w obliczu śmierci nie odrzucali jednak perspektywy życia po śmierci ${ }^{18}$. W Hospicjum od jego początków znajdowała się kaplica i posługiwał ksiądz.

Saunders rozumiała czas przygotowania się na śmierć, na pogodzenie się z nią, nie jako rezygnację czy bezczynność, a raczej jako bardzo angażującą i ważną pracę umierającego. Dlatego również potrzebne było, by był on uwolniony od bólu, aby jak najlepiej mógł to szczególne zadanie w swoim życiu wykonać - żeby to było jego zwycięstwo ${ }^{19}$.

\section{Podsumowanie}

Artykuł miał na celu ukazanie fenomenu dobra w perspektywie opieki hospicyjnej rozumianego jako konkretna postawa etyczna mająca swoje ważne konsekwencje na płaszczyźnie psychologicznej w relacji chory - osoby posługujące mu. Służył temu układ treści: wpierw ukazano dobro leżące u korzeni ruchu hospicyjnego, a następnie obecne $\mathrm{w}$ praktyce funkcjonowania hospicjów.

Paradoksem obecnym $\mathrm{w}$ rzeczywistości hospicyjnej jest to, że na nietrwałym losie ludzkim budowane jest trwałe dobro inspirujące kolejne pokolenia. Na dobro okazywane ludziom umierającym składa się wiele małych dobrych gestów, na przykład dbałość o to, by drobiazgi cenione przez podopiecznych hospicjum znajdowały się $\mathrm{w}$ ich pobliżu, ułożenie poduszek w sposób, który lubi dany chory, podobnie z ustawieniem telewizora, sposobem zasłonięcia okna itp. ${ }^{20}$ Przez takie działanie hospicja realizują słowa Saunders o ważności każdego umierającego i zobowiązaniu przyjętym przez opiekujących się nim, że dołożą wszelkich starań, by mógł żyć godnie do końca i tak też umrzeć.

17 J. Ruszkowska, op. cit., s. 92.

18 Jedna z pacjentek wspomnianego Hospicjum na dzień przed swoją śmiercią w rozmowie $\mathrm{z}$ pielęgniarką powiedziała: "Nie mogę powiedzieć, że $\mathrm{w}$ to wierzę, ale czy wolno mi powiedzieć, że mam nadzieję?"; S. de Boulay, M. Rankin, op. cit., s. 180.

19 Ibidem, s. 188.

20 Por. ibidem, s. 202. 


\section{Phenomenon of Good in Perspective of Hospice Care}

Summary

An aim of this article is to depict a phenomenon of good, understood as a ethical attitude tied with specific psychological after-effects, in caring on dying people. As it is shown, the good itself lies both on basics of modern hospice movement, as well as in daily practice of first hospice that realizes its goals - that is St Christopher's Hospice in London, which is an exemplar and source of inspiration for many others established in whole World. 